\title{
The Representation of Islamic Educational Values in Katoba Tradition of Munanese Community
}

\author{
Ardianto \\ The State Islamic Institute of Manado \\ E-mail: ardianto@iain-manado.ac.id \\ Rokmina Gonibala \\ The State Islamic Institute of Manado \\ E-mail: rukminagonibala@iain-manado.ac.id
}

\section{Hadirman}

The State Islamic Institute of Manado

E-mail: hadirman@iain-manado.ac.id

\section{Adri Lundeto}

The State Islamic Institute of Manado

E-mail: adri.lundeto@iain-manado.ac.id

\begin{abstract}
This article is the result of research that aims to explain the representation of Islamic educational values in the Katoba tradition of the Munanese community. The object of observation is Katoba ritual. In-depth interviews were conducted with informants from the Katoba tradition practitioner which called imamu, academics, researchers, traditional and cultural leaders, educational practitioners, community leaders, and youth leaders. Provision of research data sourced from the results of recording, field notes and documents. This study found that the representation of the values of Islamic education in the katoba tradition of Munanese community consists of the value of aqidah education, the value of religious education, and the value of moral education.
\end{abstract}

Keywords: values of Islamic education, Katoba tradition, Munanese community.

\begin{abstract}
Abstrak: Artikel ini merupakan hasil penelitian yang bertujuan untuk menjelaskan representasi nilai-nilai pendidikan Islam dalam tradisi Katoba pada masyarakat etnis Muna. Objek pengamatan adalah pelaksanaan ritual Katoba. Wawancara mendalam dilakukan dengan informan pengamal tradisi katoba yang disebut imamu, akademisi, peneliti, tokoh adat dan budaya, praktisi pendidikan, tokoh masyarakat, dan tokoh pemuda. Penyediaan data penelitian bersumber dari hasil pencatatan, catatan lapangan dan dokumen. Penelitian ini menemukan bahwa representasi nilai-nilai pendidikan Islam dalam tradisi katoba masyarakat etnis Muna terdiri dari nilai pendidikan aqidah / tauhid; nilai pendidikan agama; dan nilai pendidikan pendidikan moral.
\end{abstract}

Kata-kata kunci: nilai pendidikan Islam, tradisi Katoba, etnis Muna. 


\section{Introduction}

As a part of culture, tradition always objectifies its community needs and passes down its knowledge and teachings from generation to generation. Katoba tradition is one of life-cycle rituals unique to Munanese people and it has been consistently practiced and preserved in Muna District, West Muna District and other areas in Southeast Sulawesi. Even those who live outside South East Sulawesi also practice the tradition as a sign of their cultural identity. Zainal ${ }^{1}$ said that Katoba ritual is a unique identity for Munanese Moslems. In line with him are La Kadir et $\mathrm{al}^{2}$ affirming the relationship between Katoba tradition and Islamic teaching values. Moslem-majority Munanese community practices Katoba because it reflects Islamic teachings such as repentance (tobat), doing good deeds, having good attitude and all the things that can save a moslem in this world and in the hereafter. According to Munanese people, Katoba ritual is arranged for children at the age of puberty (aqil baligh) because they will have wider association so that it is important to give them teaching to guide their lives.

Katoba ritual as Munanese moslem traditional identity can be understood through the word katoba itself. Etymologically, katoba is composed of morpheme $\mathrm{ka}$ - and basic word toba. Ka- in Munanese language could mean (1) nominalization of a verb (abstract noun, tool, product), for example kaghosa (power), kaharo (broom), (2) prefix of an adjective, for example sala kawanta (trousers), (3) prefix of a verb, for example nekarato (He/She comes suddenly), (4) reduplication of a noun meaning small things such as kawale-wale (small hut), and (5) reduplication of an adjective meaning slightly or somewhat such as nokapongke-pongke (She/He is slightly deaf). ${ }^{3}$ Meanwhile, the word toba in Munanese language could mean (1) tobat (repentance), for example pogauno toba (the language of repentance), (2) insaf (repentance, atonement) for example notobamo, noangkafimo katangarino imamu (He/She was coverted, follow the imam's guidance) Imam is Islamic religious leader. (3) nothing (used in figurative language), (4) Tobatkan (religious ritual for six-year-old children: the teaching of all prohibition and good deeds in Islam by Imam that is witnessed by family members and invited guests, for example pada dongkilo anahi, dotobadamo (Right after the circumcision, the repentance ritual will be held).

Katoba ritual of Munanese people is held when boys and girls hit their puberty (aqil baligh). There is no specific number of how old the children

1 Zainal, Menjaga Adat, Menguatkan Agama: Katoba dan Identitas Muslim Muna, Yogyakarta: Penerbit Deepublish, 2017.

2 Muatan Lokal, Nilai-Nilai Kebudayaan dan Sejarah Daerah Kabupaten Muna, Muna: Dinas Pendidikan dan Kebudayaan Kabupaten Muna, 2011.

3 Zainal, Menjaga Adat.. 2017. 
should be. Hafsah, Baka, \& Aso $^{4}$ mentioned the age of eleven to thirteen, while Zainal ${ }^{5}$ mentioned 7 to 14 years old. Basically, Katoba ritual must be held when children are approaching their puberty and able to distinguish between the goods and the bads. This condition is based on the idea that a child who has practiced the Katoba must obey Gods commands and stay away from His prohibitions ${ }^{6}$. Katoba is one of the three Munanese coming of age ceremonies (kangkilo, katoba, karia) which are carried out in stages for Munanese children. ${ }^{7}$ In other words, every ritual must be carried out in order and cannot be done simultaneously. The previous ritual become a requirement for the following ritual to be performed. ${ }^{8}$

The description of Islamic Educational value representation in Katoba ritual is an effort to documenting the local wisdom among Munanese people that is inseparable from education. Education is not only about teaching intellectual values but also about teaching civility and cultural values in order to be wholly human. Education is a media. Separating culture from education could lead towards the disconnection of cultural inheritance chains between older generation and younger generation.

This qualitative research collected primary and secondary data. The primary data were speeches from Munanese people who live in Southeast Sulawesi and practiced Katoba tradition. Secondary data were collected from related published and documented resources.

The primary data was collected through interviews with informants and it had been proven to be valid. The validity is maintained by selecting main actors of the tradition as informants and following certain procedures (listen, tap, note, and record). ${ }^{9}$ The information about the implementation of Katoba ritual was specifically collected from main actor of Katoba, imamu, named La Ode Safariga from Latugho Village, Sub-District Lawa, West Muna District. Other informants were a public figure and practitioner of Munanese tradition in Bitung City North Sulawesi, a public figure and chief of tribal council from Muna District, three academics who studied Munanese culture, a youth leader and Katoba Activist from Muna District, and an elder who was the former actor of Katoba tradition from West Muna District.

\footnotetext{
${ }^{4}$ Hafsah, Wa Ode Sitti, Wa Kuasa Baka, and La Aso, Nilai-Nilai Pendidikan Karakter Pada Ritual Katoba Pada Masyarakat Etnik Muna Di Kabupaten Muna, Provinsi Sulawesi Tenggara, Prosiding International Conference on Nusantara Philosophy 2016, Fakultas Filsafat UGM, 1-14, Jogyakarta: Menara Ilmu Kanal Pengetahuan Fakultas Filsafat UGM, 2016.

5 Zainal, Menjaga Adat.., 2017.

${ }^{6}$ Hafsah, Baka, and Aso, Nilai-Nilai Pendidikan Karakter .., 2016.

7 Zainal, Menjaga Adat.., 2017

8 Zainal, Menjaga Adat.., 2017

${ }^{9}$ Sudaryanto, Metode dan Aneka Teknik Analisis Bahasa (Yogyakarta: Duta Wacana and University Press, 1993).
} 
The data were collected through observation, deep interview and documentation study. Observation was conducted to understand the location and the condition of Munanese people, whether they lived in Muna South East Sulawesi or outside South East Sulawesi. Then, the data was analysed in the field by adopting analysis method by Matthew B. Miles and Michael Huberman ${ }^{10}$.

To analyse socio-religious values of Katoba, two methods were used: identifying Katoba socio-religious values and strategies to preserve the tradition. Linguistic approach, consisting of structure analysis and meaning analysis, was chosen as the first analysis alternative. The second alternative was using sociopragmatic and anthropolinguistic. Sociopragmatic is as study focus on the use of language related to sociology.11 While anthropolinguistic is focus on studying language as cultural resources and speech as cultural practices. ${ }^{12}$

\section{Islamic Educational Values in Katoba Tradition}

Based on field analysis, the representation of Islamic educational values in Katoba tradition are categorized into three values, (1) Akidah/Tauhid Value, (2) Religious value, and (3) Moral value. The descriptoons are as follows.

\section{a. The Value of Akidah/Tauhid Education}

In terminology, Akidah is faith or belief, something that obliges the heart to acknowledge God, makes the soul peaceful and calm because of him, and strengthens the faith and clears it from any doubts ${ }^{13}$. Abu Bakar al-Jazairy ${ }^{14}$ said that Akidah is a number of truths generally accepted by human based on human intelligence, God revelation and human nature. He added, truth is in the heart, its validity and existence are naturally believed, and anything contradicting the truth will be naturally rejected. Another opinion was expressed Ahmad defining Akidah as something that is believed and held firmly and very difficult to change. According to Ahmad, people with Akidah are people who have faith in Allah subhanahu wa ta'ala, His angels, His 4 main scriptures, His messengers, predestination (Qadha and Qadar) and the hereafter.

${ }^{10}$ Analisis Data Kualitatif (Jakarta: UI Press, 1992).

11 Geoffrey Leech, Prinsip-Prinsip Pragmatik (Jakarta: UI Press, 1993).

12 Allesandro Duranti, Linguistic Anthropology (Cambridge: Cambridge University Press, 1997).

13 Suyatno Prodjodikoro, Aqidah Islamiyyah Dan Perkembangannya (Yogyakarta: Sumbangsih Offset, 1991.

14 Yunahar Ilyas, Kuliah Aqidah Islam, Yogyakarta: Lembaga Pengkajian dan Pengamalan Islam (LPPI) Universitas Muhammadiyah Yogyakarta, 1993. 
[1] Imamu : (a) Aitu dasumumpamu deki ini, kasumpano ne isilamu, amosahadha koomu deki 'Now, Let's say the oath, the oath in Islam, first of all, I would like you to say the two syahadah' (D. 267)

Children : (b) Uumbe 'Yes, Sir' (D. 268)

Imamu : (c) We sikolah dokonae sahadatain 'At school, we call them syahadatain' (D.269)

Children : (d) Uumbe 'yes' (D.270)

Imamu : (e) Dokonae dua kalimat syahadat 'also called two sentences of syahadah' (D.271)

Children : (f) Uumbe 'yes' (D.272)

Imamu : (g) Ne Wuna ini dokonae sahadha 'In Muna, it's called syahadat' (D.273)

Children : (h) Uumbe 'yes' (D.274)

The reason why imamu explained the meaning syahadat was to teach the children who were going to practice in Katoba so that they could easily understand how to say syahadah in the next step.

[2] Imamu : (a) Omangka-angkafiimu inodi ini, pada dokona aini do islamu kotughumo ini 'Repeat after me, when you finally say it, you will become a real moslem' (D.275)

Children : (b) Uumbe 'Yes (D.276)

Imamu : (c) Amoere tantusuku inodi foere dua tantusu oomu hintuoomu (the sentences of syahadat) 'I'm pointing to the sky. Point your index finger to the sky (the sentences of syahadat)' (D.277)

Children : $\quad$ (d) Uumbe 'Yes Sir" (D.278)

Imamu : (e) Naembali dosahadha dofekaware-ware randano lima, daho amoratoangko ohaeno maanano dofoere beano tantusu, nokiido bhahi ontabhala, bhahi otangkidi 'You cannot point with your open hand. Later, I'll explain what it means pointing with your fingers except your index finger, you cannot use your thumb, or your pinky' (D.279)

Children : (f) Uumbe 'yes Sir (D.280)

Imamu : (g) Dofoere tantusu potalagho tampuno ne dawatu, angkafi idi nasebantara itu amoere tantusuku peda itu 'Put your index finger in front of the tip of your nose, like this. Look at me first everyone. I put my index like this.' (D.281)

Children : (h) Uumbe 'Yes' (D.282) 
The speech (2.a-h) above shows how imamu explained the essence of saying the syahadat. Syahadat becomes a mandatory perquisite to become a Moslem, As mentioned in the speech (a) Omangka-angkafiimu inodi ini, pada dokona aini do Islamu kotughumo ini 'Repeat after me, when you finally say it, you will become a real moslem'. Then imamu asked the children to follow what was said and done by imamu, verbal and nonverbal instruction. Verbal and nonverbal expression of syahadat in Kotoba tradition must be done together and cannot be separated.

From the speech (2.a-h) it can be understood that in Katoba tradition, by following imamu, a child who is Katoba-ed is sworn in order to make him a Moslem. To make them understand, and imamu explains that sahadha in Munanese language means 'syahadat', and at school it is called syahadatain or two sentences of syahadat.

After teaching attitude, position and gesture (nonverbal) of syahadat, imamu continue explaining wambano toba 'the language of repentance' as mentioned in the following script

[3] Imamu : (a) Angka-angka fiimu: astaghfirullahal adzim. Ashadu allah ilaaha ilallah washadu annamuhammadurrasulullah. 'I bear witness there is no God but Allah and I bear witness Muhammad is the messenger of Allah' (Original sentence is in Indonesia). Wamba wunano: Aobha mina bhe ompu, sampu-mpuuno nisomba sapaeno Allah taala. Aobha anabi muhammadhi katudu-tudunono allah taala. Alhamdulillahi robbil alamiin. Hapuleimu hulamu itu. (D.283)

Children : (b) Uumbe 'Yes' (D.284)

Imamu : (c) Tanda-tandai nagha sahadha itu 'Please memorize the syahadat' (D.285)

Children : (d) Uumbe 'Yes Sir' (D286)

Speech (3.a-d) above shows the step of saying the syahadat for children in katoba. They had to say language of repentence 'astaghfirullahal adzim' (I seek forgiveness of Allah the mighty) and declare syahadat by following imamu. The language of repentance is the symbol of Taubat. Repentance in katoba tradition refers to three sins, kahalano dukuno lalo 'sins of the heart', kahalano pogau 'sin od the tongue', and kahalano diu 'sin of action'.15

Speech (3.a-d) above shows the strategy used by imamu in guiding the children to take an oath to become a Moslem. This communication used in order to ask their agreement to be Katoba-ed. With that agreement, imamu had successfully guide children of Muna to Islam. The agreement can be seen

15 Zainal, Menjaga Adat.., 2017, 151 
from their response (b) uumbe 'Yes'. This verbal response has a very important meaning because it is an oral agreement of the children to voluntarily embrace Islam as their religion.

When someone declares the syhadat, she/he will formally become a moslem. By voluntarily admitting the oneness of Allah and the apostolic of prophet Muhammad, someone has the right to be called a Moslem. Therefore, for Munanese people, Katoba tradition is a ritual of islamization and syahadat is the peak of the tradition. Furthermore, Munanese children are also advised to glorify the syahadat. As mentioned in the following speech.

[4] Imamu : (a) Osahdha itu-itua dofosibhalae bea 'You must glorify the syhadat' (D.287)

$\begin{array}{ll}\text { Children } & : \text { (b) Uumbe 'Yes (D.288) } \\ \text { Imamu } & : \begin{array}{l}\text { (c) Nembali ewangantoomu isilamu 'It is our best } \\ \text { defense' (D.289) }\end{array} \\ \text { Children } & : \text { (d) Uumbe 'Yes' (D.290) }\end{array}$

Speech (4.a-d) above describes three position of syahadat, memorizing the syahadat (mind), glorify the syahadat (heart), and use it as a defense to shield oneself from apostasy as mentioned in the verbal expressionl syahadat menjadi ewanga 'weapon' 'Nembali ewangantoomu Isilamu '(syahadat), is our best defense'

[5] Imamu : (a) Ramapano oisilamu noeregho lima ruku anoa. (b) Osadha otumandai eemo, pasina osumambaheamu, pasina omoasamu, pasina ozakati kewajibano kamokulamu paeho hintua. (c) Dahumaji imu dakodoi maka dakumala dahumajiimu 'There are five pillars of islam. Syahadat that you should remember, obligatory prayer, fasting in the month of Ramadhan, zakat, for now it's your parents responsibility, and finally pilgrimate to Mecca and it's for when you have enough money (D.447-449)

Children : (d) Uumbe 'Yes' (D.450)

Speech (5.a-d) shows how imamu introduce the five pillars of Islam to Munanese children through Katoba tradition. First, osahadha 'syahadat', In speech (b) Osadha otumandai eemo ......'Syahadat that you should remember...' Imamu taught the children to always remember syahadat because it is the foundation of Islam. When one's syahadat is canceled, their Islamic status will be automatically cancelled. The speech also shows how an Imamu also advice the children to implement syahadat, obligatory prayer, fasting in the month of Ramadhan, zakat and pilgrimate to Mecca. However, Imamu explained that zakat is still their parent responsibility and Haj (pilgrimate) is obligated 
when they are financially capable. As mentioned in the speech pasina ozakati kewajibano kamokulamu paeho hintua. Dahumaji imu dakodoi maka dakumala dahumajiimu '.... for now, zakat is your parent responsibility and Haj is when you have enough money'.

Then, the speech in Katoba contains a message about the importance of maintain one's akidah.

[6] Imamu : (a) Otandaamu gholeo itu ini oisilamumu. (b) Kaisilamu itu soano maighoono nelahaea, nomaigho newutomu 'Today you become a moslem. Your islam is for no one other than you' (D.438-439)

Children : (c) Uumbe 'yes (D.440)

Imamu : (d) Bhalihaono gholeoitu ini padamo dosakusiangko bha kamokulahi, padamo dopowise bhe idi. (e) Oisilamumu kotughu. (f) Naewine naefua bhalihaono kamokulaamu paemo namesua isilamu, potahamigho kansuru kaisilamumu sampe damate. 'today your islam is witnessed by your parents and by me. But if one day, for example, your parents leave Islam, you must keep your Islam, until you die' (D. 441-443)

Children : (g) Uumbe 'Yes' (D.444)

The speech (6.a-g) above describes how imamu warn the children about the importance of hold firmly to their Islamic faith forever. (a) Otandau gholeo itu ini oisilamumu. (b) Kaisilamu itu soano maighoono nelahaea, nomaigho newutomu "Today you are a Moslem. Your Islam is for no one other than you'. The speech also indicates that the syahadat is not forced to the children. Basically, they are only guided to embrace the religion themselves. Then, imamu added, (f) Naewine naefua bhalihaono kamokulaamu paemo namesua isilamu, potahamigho kansuru kaisilamumu sampe damate 'If one day, for example, your parents leave Islam, you must keep your Islam until you die'. Parents and all invited guests act as witnesses. The effort to maintain the akidah is up to the children. They are responsible for their own faith.

\section{b. The Value of Religious Education}

Religious Educational values taught to Munanese people in Katoba tradition is Ghusl (spiritual bath) including types of purification water, obligatory prayer, fasting in the month of Ramadhan and zakat (charity). Before starting the ritual, the children should take a symbolic spiritual bath. The activity is led by imamu or modhi. This is a symbol to purify the children of Katoba. 
From the field study, it was found that some nonverbal processes of Katoba served as devices or tools of chasity. Starting from imamu reciting a prayer on a thermos then bath the children, All of these are full of symbolic meanings. Moreover, verbal expression is full of teachings representing the values of religious education including ablution, obligatory prayer, fasting in the month of Ramadhan and zakat.

\section{1) The Teaching of Ablution (Wudhu)}

Wudhu is one of obligatory requirement for prayer. Someone who are going to do the prayer, pillar number two, must take wudhu. Otherwise, his/her prayer will not be accepted. However, if she/he can not find water or suffers from certain illness, she/he can choose tayamum as the alternative.

In Katoba, the children are advised to take wudhu before going to far and school. As a Moslem they should always be in a state of purity. Other than as a prerequirement for prayer, Wudhu can become a way to erase sins.

[7] Imamu : (a) Pada omekabusa doghomemu ghaghe deki. (b) Osuana tolu paku, okema tolu paku 'After you wash your private part, you wash yout feet three times each, starting from the right foot.' (D.420-421)

\begin{tabular}{|c|c|}
\hline Children & (c) Uumbe 'Yes (422) \\
\hline Imamu & $\begin{array}{l}\text { : (d) Pasina doghome lima, pasina dereghumu 'Then } \\
\text { wash yout hands, and your face' (D.423) }\end{array}$ \\
\hline Children & (e) Uumbe 'Yes' (D.424) \\
\hline Imamu & $\begin{array}{l}\text { (f) Motokahano tora kansuru dewudu 'perfect it with } \\
\text { wudhu. That's the perfection of purity (D.425) }\end{array}$ \\
\hline Children & (g) Uumbe 'Yes (D.426) \\
\hline Imamu & $\begin{array}{l}\text { : (h) Pasina dobasamu sahadha ani ini 'The, read the } \\
\text { syahadat' (D.427) }\end{array}$ \\
\hline Children & (i) Uumbe 'Yes' (D.428) \\
\hline Imamu & $\begin{array}{l}\text { (j) Sapada opada omeghomesi ghaghemu, owanu } \\
\text { limamu omereghufi, pasina omewudu basamu } \\
\text { sahadhamu. (k) Tamaka fopaghindulu deki toba } \\
\text { (astaghfirrulahal adzim. Ashadu allah ilaaha ilallah wa } \\
\text { ashadu annamyhammadarrasulullah) 'After washing } \\
\text { your feet, hands, and face, take wudhu and then say the } \\
\text { syahadat right after reciting the repentance language. } \\
\text { (astaghfirrulahal adzim. Ashadu allah ilaaha ilallah wa } \\
\text { ashadu annamuhammadarrasulullah)' (D.429-430) }\end{array}$ \\
\hline
\end{tabular}




\begin{tabular}{|c|c|}
\hline Children & : (l) Uumbe 'Yes' (D.431) \\
\hline Imamu & $\begin{array}{l}\text { (m) Dopada dolimba we kakusu insa allah intaidi ini } \\
\text { donggelamo tora. 'After that, Insyaallah we have been } \\
\text { purified (D.432 }\end{array}$ \\
\hline Children & (n) Uumbe 'Yes' (D.433) \\
\hline Imamu & $\begin{array}{l}\text { (o) Okumalamo wesikola, okumalamu we galu } \\
\text { dousahagho intaidi ini dopada dewudu maka dokala } \\
\text { "Whenever you go to school or go to farm, you should } \\
\text { always be in a state of cleanness' (D.434) }\end{array}$ \\
\hline Children & (p) Uumbe 'Yes' (D.435) \\
\hline Imamu & $\begin{array}{l}\text { (q) Dodhagami kanggelano ghulu, bhe kanggelano lalo. } \\
\text { Aitu emo itu isilamu 'Keep the cleanness of your body } \\
\text { and heart. Then declare your syahadat' (D.436) }\end{array}$ \\
\hline Children & : (r) Uumbe 'Yes' (D.437) \\
\hline
\end{tabular}

Speech (7.a-r) above mentions about cleanness after defecating and urinating and how to take a perfect wudhu. From the toilet, the children must wash their feet. Three times for right foot then three times for left foot. Next step is to wash their hand and face. By doing so, a moslem can become clean once again. As mentioned in part (j) Sapada opada omeghomesi ghaghemu, owanu limamu omereghufi, pasina omewudu basamu sahadhamu. After that the children are suggested to directly take ablution, as mentioned in part (f). Motokahano tora kansuru dewudu 'and then perfect it with wudhu'. The children begin the wudhu by reciting basmallah, then washing their hands, gargling, inhaling water to clean the sinus, and after that proceeding to the usual steps of wudhu; washing face three times, washing hands from fingertips to elbows three times, wiping ears, and washing feet three times up to the ankle. In addition, the children of Katoba also learn types of water used for purification or wudhu in Islam.

Another advice is for the children to always keep their wudhu, even when they go to school, farm or do other daily activity. As mentioned in part (o) Okumalamo wesikola, okumalamu we galu dousahagho intaidi ini dopada dewudu maka dokala 'Whenever you go to school or go to farm, you should always be in a state of cleanness'. According to Munanese Moslems, pure or cleanness is Physical and mental or body cleanness (kanggelano lalo) and heart cleanness (kanggelalo lalo) as mentioned in part (q) Dodhagami kanggelano ghulu, bhe kanggelano lalo. Aitu emo itu isilamu 'Keep the cleanness of your body and heart. Then declare your syahadat'

\section{2) The Teaching of Sholat}

One of Moslem obligations is prayer. In katoba Imamu emphasize the teaching of prayer. After the ritual processes are done, Imamu call a child to 
the front and teach him/her how to pray well while other children are watching. In the following speech, look how Imamu give advices about their Islam.

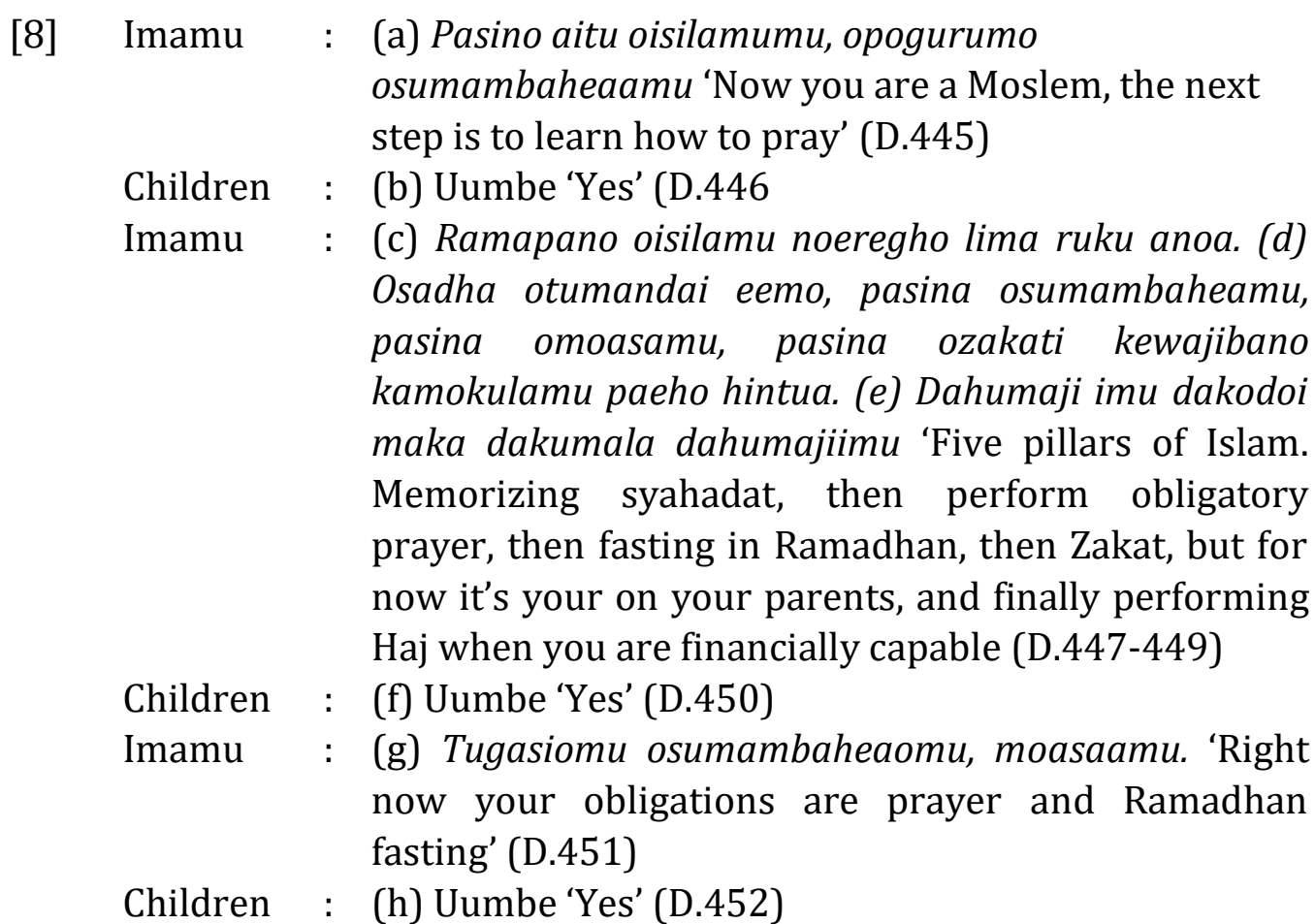

The speech (8.a-h) above explains the obligation of Munanese children after they declare their Islam. These obligations are mentioned in this part (a) Pasino aitu oisilamumu, opogurumo osumambaheaamu 'Now you are a Moslem, the next step is to lear how to pray.' (g) Tugasiomu osumambaheaomu.... 'Righ now your obligations are prayer ...'. This part shows how an Imamu emphasized the children to learn how to pray starting from stating their niat (intention) to salam (prayer closing). And part (f) shows the children readiness to perform shalat. Imamu words in Katoba ritual are followed religiously by the children by saying uumbe 'Yes' as an expression of agreement to perform the prayer.

\section{3) The teaching of Fast}

After the teaching of prayer, the children are taight about Ramadhan fasting, an obligatory fast in the month of Ramdhan. Meanwhile, sunah fasting is not discussed. As the following speech describes.

[9] Imamu : (a) Debasa haroa oangkafi kaawu kamokulahimu, dopoasa oangkafi kaawu kamokulahimu 'They read haroa follow your parents, and about fasting, also follow your parents' (D.387) 


$\begin{array}{ll}\text { Children } & : \text { (b) Uumbe 'Yes' (D.388) } \\ \text { Imamu } & : \text { (c) Aitu oisilamumu, osumambaheamo, omoasamo itu } \\ & \text { 'Now you are a Moslem. So, pray and fast.'(D.389) } \\ \text { Children } & : \text { (d) Uumbe 'Yes' (D.390) }\end{array}$

Children of 7-11 years old usually doesn't know how to recite niat for fasting and they usually imitate their parents, as mentioned in the expression (a) ... dopoasa oangkafi kaawu kamokulahimu '..., For fasting just follow your parents'. After katobe, the children still need to memorize the niat, so imamu suggests the parents or grandparents or older siblings to cast certain dua on a glass of water and give it to the children after reciting niat for fasting and breakfasting. And that should be done until they can independently or memorize the niat.

Form the speech it is very clear when a child agree to become a Moslem, she/he agree to perform obligatory prayer and Ramadhan fasting. It also indicates that after the katoba the children must perform the obligations. The agreement is shown by the expression uumbe 'Yes' as a response to imamu words.

\section{4) The Teaching of Zakat}

In etimology, zakat is originated from Arabic word az-zakah. Az-zakah is masdar (verbal noun) of fiil madli (past form of verb) 'zaka' which means anNamaa' 'grow', az-Zayadah 'fruitful', as-Sholah 'goodness', or it could also mean giving a certain amount of wealth to other people for the sake of purifiying the wealth and the owner of the wealth. By doing zakat (charity), the giver will get fruitful rewards from Allah and be placed in the noble position with Allah and be purified and clean. ${ }^{16}$.

Sayyid Sabiq ${ }^{17}$ explained that zakat is a name for Allah's portion of a Moslem wealth which must be given the poors. Through zakat, the owner wishes for Allah's blessing on his wealth, the cleanness of his soul and protected from miserliness. It also erases the feeling of envy and hatred between the poors and the riches and leads to many benefits (Asnaini, 2008, p. 7). It cleans the soul of the giver (muzakki), creates prosperous society and creates a life where people are sharing, helping and supporting for a better harmonious life.

Zakat is one of Moslem obligations after prayer. As Allah said in the Qur'an Surah Albaqarah verses 43 and 110, zakat is an obligation and refuse to paying zakat is a form of kufr towards Allah.

${ }^{16}$ M. Jawad Mughniyah, Fiqih Imam Ja'far Shadiq, Jakarta: Lentera, 2009.

17 Asnaini, Zakat Produktif Dalam Perspektif Hukum Islam, Yogyakarta: Pustaka Pelajar, 2008. 


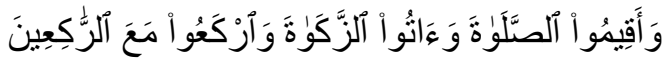

Translation:

"Ans establish prayer and give zakah and bow with those who bow." (QS. AlBaqarah [2]: 43)

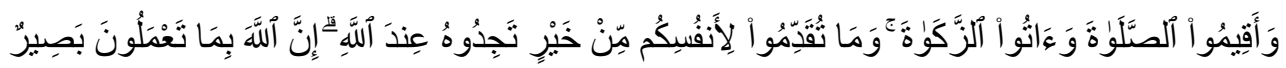

Translation:

"And establish prayer and give zakah, and whatever good you put forwords for yourselves - you will find it with Allah. Indeed, Allah of what you do, is seeing." (QS. Al-Baqarah [2]: 110)

Examining the verses above and following hadith from the prophet Muhammad sallahu 'alaihi wassalam, whether they are slaves or free people, men or women, children or parents, every Moslem must give zakat under the Islamic rules and conditions called sharia laws. As mentioned in this hadith,

Narrated by Ibnu Umar r.a: "Allah's Apostle enjoined the payment of one sa' of dates or one sa' of barley as Zakat-Ul-Fitr on every Moslem slave or free, men or women, young or old, and he ordered that it be paid before the people went out to offer the 'Id prayer. (HR Bukhari, No. 1503: Muslim, No.984).

In Katoba, Imamu also mentions about zakat. However, he informs the children that since they are young, zakat is their parent responsibility. As stated in the following speech:

[10] Imamu : (a) Ramapano oisilamu noeregho lima ruku anoa. (b) Osadha otumandai eemo, pasina osumambaheamu, pasina omoasamu, pasina ozakati kewajibano kamokulamu paeho hintua. (c) Dahumaji imu dakodoi maka dakumala dahumajiimu 'Five pillars of Islam. Syahadat you must memorize, Performing obligatory prayer, fasting in Ramadhan, and give zakat which is your parent responsibility. If you have enough money, then pilgrimate to Mecca. (D.447-449)

Children : (d) Uumbe 'Yes' (D.450)

The speech describes how imamu explain the obligation of zakat. And it is still their parent responsibility to pay their zakat. pasina ozakati kewajibano kamokulamu paeho hintua... 'For now Zakat is your parent responsibility... '. Parents are responsible to pay zakat for their children until they become adults and independent. This responsibility is included in parent obligatory support. Imam Syafii stated that those who are given 
support are direct descendants or direct ancestors of the family, for example from parents to children to grand children and continue to great grandchildren or from children to parents to grandparents and continues to great grandparents. So, zakat is a bit different from other two afromentioned obligation.

This advice has been followed by all Munanese children even after they have work and can earn for themselves. In other words, parents are responsible for the children zakat as long as they are not married.

\section{c. The Value of Moral Education}

Akhlak is a loanword from Arabic which has meaning realted to attitude or morals of someone. Some experts said that akhlak is a human character that produces behaviors easily and spontaneously without thinking or studying 18 . Akhlak can also be defined as human natural impulse that takes in good and bad form ${ }^{19}$. Imam Al Ghazali interpreted Akhlak as a trait embedded in the human soul which can easily produce behaviors and action without thinking and reasoning 20 .

In Katoba tradition, the teaching of akhlak covers the value of morals to ama 'father', ina 'mother', isa 'older siblings' and ai 'younger siblings'. However, the teaching is not only for family members but also applied for public such as elders, adults and other older Munanese children. So, the children in Katoba are taught to have morals as a provision to live in the community.

The obligation to be polite towards parents is stated in Qur'an surah alIsra verse 23:

"And your lord had decreed that you not worship except Him, and to parents, good treatment. Whether one or both of them reach old age [while] with you, say not to them [so much as], 'uff' and do not repel them but speak to them a noble word" (QS. al-Isra [17] : 23).

\section{1) Morals towards Ama (Father)}

Akhlak education in Katoba empashizes on morals to parents and obeying orders as long as they are not against sharia laws. If parents ask children to do ma'siyat or go against Islam, the children must not obey them. untuk tidak mematuhinya. The verbal expression of the teaching can be read in the following speech.

${ }_{18}$ M. Abdul Mujieb, Ahmad Ismail, and Syafi'ah, Ensiklopedi Tasawuf Imam Al-Ghazali Mudah Memahami Dan Menjalankan Kehidupan Spiritual, Jakarta: PT. Mizan Publika, 2009.

${ }^{19}$ Ibid.

20 Tatapangarsa, 1984, p. hlm. 14. 
[11] Imamu : (a) Dofotola andoa dobhalo merimbae 'When you parents call you, soon answer to their calling' (D.157)

Children : (b) Uumbe 'Yes' (D.158)

Imamu : (c) Ane dofotola andoa mina naembali dobhalo" omokohaeno" "When they call you, you must not say "what?" (D.158)

Children : (d) Uumbe 'Yes' (D.160)

In the speech (11.a-d) imamu teach the children to always answer to their parents calling. They must not ignore it and even answer it with only "what?" Children are not allowed to talk with their parents impolitely. (c) Ane dofotola andoa mina naembali dobhalo" omokohaeno" "When they call you, you must not say "what". Saying ohaono 'what' to parents or older people such as grandparents and teachersin Munanese culture is considered very impolite.

Dofotudu doangkafie "obey their order" means when a parent order the children to do good deeds or to practice Islam (prayer, fasting, reciting Qur'an, and so on), the children must obey the order. That is moral values to parents especially father taught in Katoba ritual. Children must answer their parent calling with good manner and must not say 'what' to them or ignore them. One way to give polite response is by saying uumbe 'Yes'.

\section{2) Morals towards Ina (Mother)}

While previous speech is especially for father, the following speech contains advice to treat Ina or mother well.

[12] Imamu : (a) Dofotola kamokula robhine dobhalo merimbha. 'Mother's calls must be answered immediately' (D.202)

Children : (b) Uumbe 'Yes' (D.203)

Imamu : (c) Paemo naemblai natumolako inamu, dobhaloe ohaeno ina, panaembali nagha, tabea omoko uumbe. 'When you mother calls you, you must not answer them with 'what mom?', say 'Yes mom" (D.204)

Children : (d) Uumbe 'Yes' (D.205)

Speech (12.a-d) comprehend a message to be kind to mother. Imamu told that a child must immediately answer to his/her mother's calls, even when they become an adult. She/he cannot answer her with simply 'what' or ignore her. Children must treat their mothers politely and gently. Paemo naemblai natumolako inamu, dobhaloe ohaeno ina, panaembali nagha, tabea omoko uumbe. 'You must not answer your mother with 'what mom?' , say 'Yes Mom'. Ohaono or 'what mom?' is considered very impolite and improper 
response of children to their mother. One way to give polite response is by saying uumbe 'Yes mom'.

Speech (11) and (12) shows the importance of polite treatment of children to parents. In addition, another resource said, "Okamokula beano doharagamie. Kamokula moghane kabholosino Kakawasa. Kamokula robhine kabholosino anabi. Dadi okamokula beano dotehie. "Parents must be respected and appreciated. Father is a representative of God on earth and mother is like a representative of prophet on earth. So, they must be obeyed".

In other words, a child needs to take care, protect, and maintain the good name of his/her parents. Because in Munanese perspective (in katoba) Katoba traditional values taught to Munanese people is inseparable from Munanese culture. The message in those verbal expressions has a value of taking care and protecting parents and maintaining the good name of parents. $^{21}$

\section{3) Morals towards Isa (Older Sibling)}

After that, the children are told to treat their siblings well. The following speech contains a message to treat and respect older brother or sister.

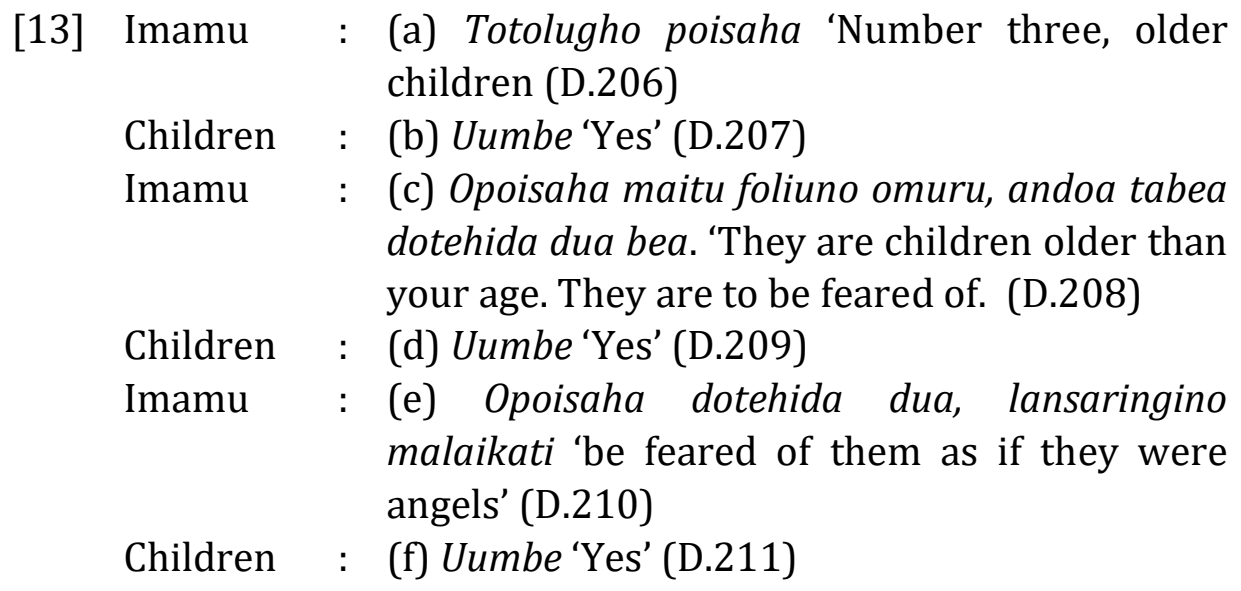

The message of the speech above is for the children to be wise with their action or attitude in front of older children, including their older siblings or other children. Even when they become adults. It is very wise to respect and obey the older ones as long as they are not against Islam. Kakak Isa has general meaning. It can be older siblings or older children. The term does not always refer to blood related siblings. An Isa is to be feared in the good way. When older children call or ask younger ones to help them with housechores, the younger ones must obey and help them. As said by imamu (c) Opoisaha maitu foliuno omuru, andoa tabea dotehida dua bea. "They are children older than your age, they are to be feared of'.

${ }^{21}$ La Ode Sidu Marafad and La Niampe, Buku Ajar Sekolah Dasar FALIA (Ungkapan Falia Dalam Pendidikan Karakter), Yogyakarta: Pustaka Puitika, 2017. 


\section{4) Morals towards $\mathrm{Ai}$ (Younger Sibling)}

The last message is to be kind to younge children, whether they are siblings or other children. The message is mentioned in the following speech,
[14] Imamu : (a) Popagho, opoaiha 'Number four, younger children'(212
Children : (b) Uumbe 'Yes' (213)
Imamu : (c) Opoahiha maitu aihimu hintu, olalie hintu omuru 'They are your siblings, younger than you' (214)
Children : (d) Uumbe 'Yes' (215)
Imamu : (e) Opoaiha beano dooloanda, doasianda, lansaringino muumini 'You must love and treat them like a mukmin' (216)
Children : (g) Uumbe 'Yes' (217)

Imamu told the children to kindly interact and behave with older children. They must treat them with love and care as if they were mukmins. (e) Opoaiha beano dooloanda, doasianda, lansaringino muumini 'You must love and treat them like a Mukmin'. This message has a very deep meaning. As Moslems and mukmins all children of Katoba specifically and Munanese people generally must love and treat each other well, like they love their own mother, father and siblings.

\section{Conclusion}

From discussion and analysis above, it can be concluded that the representation of Islamic educational values in Katoba ritual among Munanese people from South East sulawesi and in other area of Sulawesi is focus on three aspects (1) The values of akidah education, including (a) the affirmation of Tauhid rububiyah, uluhiyah, and ubudiyah, (b) the declaration of syahadat (syahadat tauhid and syahadat rasul), (c) exaltation of syahadat and (d) use syahadat as a shield to protect a Moslem from murtad; (2) The values of religious education including make wudhu (Ablution), (b) learn to how to pray, (c) learn about fasting, (d) zakat or charity; (3) The values of Morals, including (a) morals to ama 'father', (b) morals to ina 'mother', (c) moral to isa 'older siblings', and (d) morals to ai 'younger siblings'.

\section{Bibliography}

Ahmad, Muhammad Abdul Qadir, Metodologi Pengajaran Agama Islam, Jakarta: Rineke Cipta, 2008.

Alwasilah, A. Chaedar, Pokoknya Kualitatif, Jakarta: Dunia Pustaka Jaya, 2008.

Asnaini. Zakat Produktif Dalam Perspektif Hukum Islam, Yogyakarta: Pustaka Pelajar, 2008. 
Duranti, Allesandro, Linguistic Anthropology, Cambridge: Cambridge University Press, 1997.

Hadirman, Sejarah Dan Bahasa Figuratif Dalam Tradisi Katoba Pada Masyarakat Muna, AQLAM: Journal of Islam and Plurality, Vol. 2, No. 1, Juli 2017.

Hafsah, Wa Ode Sitti, Wa Kuasa Baka, and La Aso, Nilai-Nilai Pendidikan Karakter Pada Ritual Katoba Pada Masyarakat Etnik Muna Di Kabupaten Muna, Provinsi Sulawesi Tenggara, Paper in International Conference on Nusantara Philosophy 2016, Fakultas Filsafat UGM, 1-14, Jogyakarta: Menara Ilmu Kanal Pengetahuan Fakultas Filsafat UGM, 2016.

Ilyas, Yunahar, Kuliah Aqidah Islam, Yogyakarta: Lembaga Pengkajian dan Pengamalan Islam (LPPI) Universitas Muhammadiyah Yogyakarta, 1993.

Jawas, Yazid bin Abdul Qadir, Syarah 'Aqidah Ahlus Sunnah Wal Jama'Ah, Bogor: Pustaka Imam Asy-Syafi'i, 2006.

La Kadir, dkk, Muatan Lokal, Nilai-Nilai Kebudayaan Dan Sejarah Daerah Kabupaten Muna, Muna: Dinas Pendidikan dan Kebudayaan Kabupaten Muna, 2011.

Leech, Geoffrey, Prinsip-Prinsip Pragmatik, Jakarta: UI Press, 1993.

Marafad, La Ode Sidu, and La Niampe, Buku Ajar Sekolah Dasar FALIA (Ungkapan Falia Dalam Pendidikan Karakter), Yogyakarta: Pustaka Puitika, 2017.

Miles, Matthew B., and A. Michael Huberman, Analisis Data Kualitatif, Jakarta: UI Press, 1992.

Mughniyah, M. Jawad, Fiqih Imam Ja'far Shadiq, Jakarta: Lentera, 2009.

Mujieb, M. Abdul, Ahmad Ismail, and Syafi'ah, Ensiklopedi Tasawuf Imam AlGhazali Mudah Memahami Dan Menjalankan Kehidupan Spiritual, Jakarta: PT. Mizan Publika, 2009.

Prodjodikoro, Suyatno, Aqidah Islamiyyah Dan Perkembangannya, Yogyakarta: Sumbangsih Offset, 1991.

Spradley, James P, Metode Etnografi, Yogyakarta: Tiara Wacana Yogyakarta, 1997.

Sudaryanto, Metode Dan Aneka Teknik Analisis Bahasa, Yogyakarta: Yogyakarta: Duta Wacana University Press, 1993.

Sugiyono, Metode Penelitian Kuantitatif, Kualitatif Dan $R \& D$, Bandung: Alfabeta, 2011.

Tatapangarsa, Humaidi, Pengantar Kuliah Akhlak, Surabaya: Bina Ilmu, 1984. Zainal, Asliah, Menjaga Adat, Menguatkan Agama: Katoba Dan Identitas Muslim Muna, Yogyakarta: Penerbit Deepublish, 2017. 